\title{
Review of Participatory Epizootiology Research of Contagious Bovine Pleuropneumonia at the Department of Veterinary Public Health and Preventive Medicine, University of Ibadan, Nigeria (2007-2015)
}

\author{
Babalobi O. O..$^{1,2^{*}}$ and Alhaji N. B. ${ }^{1,3}$ \\ ${ }^{1}$ Department of Veterinary Public Health and Preventive Medicine, Faculty of Veterinary Medicine, University of Ibadan, \\ Ibadan, Nigeria. \\ ${ }^{2}$ Chairman, Eruwa Faculty Veterinary Field Station, University of Ibadan (2007-2009, 2014-2018). \\ ${ }^{3}$ Public Health and Epidemiology Unit, Ministry of Livestock and Fisheries Development, Minna, Niger State, Nigeria. \\ *Corresponding author. Email: tayobabalobi@gmail.com. Tel: +234-816-753-8536; +234-805-530-1991. \\ Copyright @ 2018 Babalobi and Alhaji. This article remains permanently open access under the terms of the Creative Commons Attribution License \\ $\underline{4.0}$, which permits unrestricted use, distribution, and reproduction in any medium, provided the original work is properly cited.
}

Received 6th April, 2018; Accepted 30th April, 2018

\begin{abstract}
This is a review of research application of Participatory Epizootiology to investigate Contagious Bovine Pleuropneumonia among pastoralists in Oyo State and Niger State, Nigeria, between 2007 and 2015, at the Department of Veterinary Public Health and Preventive Medicine, Faculty of Veterinary Medicine, University of Ibadan where the first author, a Veterinary Epidemiologist Lecturer/Researcher teaches Participatory Epizootiology Research as part of PVM 711: Advanced Epizootiology, a compulsory Course in the three Master degrees curriculum of the Department since 2004. He subsequently designed a PhD research project on the application of Participatory Epizootiology to the Igangan Grazing Reserve and got a University Senate Research SRG/FVM/2006/9A to that effect. In 2007, the Principal Veterinary Officer of the Faculty Eruwa Veterinary Field Station in Ibarapa East Local Government Area, Oyo State, south-western Nigeria, reported to the first author (then Chairman, Eruwa Veterinary Field Station), a suspected case of Contagious Bovine Pleuropneumonia incidence at the Igangan Grazing Reserve. The diseased lung samples of dead infected cattle he brought were confirmed by gross and histopathological examinations at the Faculty's Department of Veterinary Pathology. From 2011 to 2015, the second author adopted the PE PhD-design (with other conventional veterinary research approach) to investigate Contagious Bovine Pleuro-pneumonia prevalence in Niger State, North-central Nigeria, first for his Masters (2011), followed with a PhD (2015). Result indicated that Contagious Bovine Pleuropneumonia in enzootic in Oyo and Niger State, Nigeria with a $77.67 \%$ of CBPP outbreaks in Niger State, Nigeria occurring in the dry season, and a prevalence of $8.73 \%$. Participatory Epizootiology is a cheap, low capital involvement of traditional settler beneficiaries in identification of enzootic animal problems and their Community Based Animal Health training need. Participatory Epizootiology should be adopted in combination with conventional veterinary methods for effective Contagious Bovine Pleuropneumonia surveillance and control techniques in Africa.
\end{abstract}

Key Words: Participatory Epizootiology, Contagious Bovine Pleuropneumonia, Surveillance and Control, University of Ibadan, Nigeria.

\section{INTRODUCTION}

Participatory Epizootiology (PE) is the use in Veterinary Medicine of participatory approach, techniques or methods to collect qualitative epizootiological data or intelligence contained within a community by observations, existing veterinary knowledge and traditional oral history, to improve understanding of animal health issues (Schwabe, 1984; Mariner and Paskin, 2000; Catley and Admassu, 2003; Babalobi and Idowu, 2005). Also called Participatory 
Epidemiology in Human Medicine, it is a decision or actionoriented intelligence gathering activity (FAO 2000, Catley and Leyland, 2001). The use in Veterinary Medicine has been to improve understanding of animal diseases and veterinary services and community participation to design solutions to disease problems with livestock keepers' input. This has been upheld and promoted by both the Food and Agricultural Organization FAO and the International Office of Epizootics OIE (Mariner and Paskin, 2000). According to Shimshony (2009), the birthplace of PE is Southern Sudan in 1993.

PE is known to be introduced and established in Nigeria via two routes:

1. Through postgraduate academic/research training by the first author, a Lecturer/Researcher and Consultant Epizootiologist (Veterinary Epidemiology and Economics) at the Department of Veterinary Public Health and Preventive Medicine DVPHPM, Faculty of Veterinary Medicine FVM, University of Ibadan UI, Ibadan, Nigeria, from 2004 (Babalobi 2012a); and

2. Through the 2008-2009 Early Detection Reporting Surveillance: Avian Influenza in Africa (EDRSAIA) capacity building exercise on Participatory Epidemiology (PE) and Participatory Disease Surveillance (PDS) for Highly Pathogenic Avian Influenza (HPAI) for veterinary personnel in Nigeria by the International Livestock Research Institute(ILRI) (Babalobi, 2011b).

The first author's interest and commitment to PE and its various components is traced to:

1. Publications of and personal 2003-2004 e-mail interactions with Dr. Andy Catley, then of Tuft's University, who was serving at the Community Animal and Participatory Epidemiology CAPE Unit, PACE Programme, OAU/IBAR, Nairobi, Kenya. (Catley, 1999, 2005).

2. Christian Veterinary Mission (CVM) Seattle, Washington-organized International workshop on the training (of trainers) of Community Animal Health Workers held in Jinja, Uganda, from Sept. 22nd through October 6th, 2005; and

3. Various PE CDs and training publications by Catley and Mariner (2001) and others such as AU/IBAR (AUIBAR (2002), FAO (Mariner and Paskin (2000), IIED (Catley and Mariner 2002), OIE (Shimshony 2009).

The official declaration of the successful eradication of Rinderpest in animals in 2011 became only the second successfully eradicated infectious disease after the prior eradication of smallpox in humans (OIE 2011). However, little was highlighted on the role of part of $P E$ in the successful eradication of Rinderpest. FAO (2012). Initially tried on small scale community-based health interventions in East and Central Africa, the PE approach was officially and successful adopted for the Global Rinderpest Eradication Programme. In Nigeria, PE was also successful adopted in the eradication of the 2006 Avian Influenza threat in Nigeria under the Early Detection Reporting Surveillance: Avian Influenza in Africa EDRSAIA (Babalobi, 2011b). Obviously, the implementation of the EDRSAIA PE training must have "opened the eyes" of the government veterinarians and prepared them to the efficacy of PE methods application (Anzaku, 2009).

Contagious Bovine Pleuropneumonia (CBPP) is a fatal, infectious and contagious respiratory disease of cattle, caused by Mycoplasma mycoides subspecies mycoides (Mmm) strain of the Class Mollicutes, with up to 50 to $90 \%$ mortality (OIE, 1995, 2005; Thomson, 2005). All ages of cattle are susceptible but young cattle develop joint swellings rather than lung infections. Many cattle show no disease signs despite being infected and others recover quickly after a transient mild disease, yet they can carry infection for as long as two years and may be responsible for passing on infection at a later date (FAO 1997). Up till 2004, CBPP was the only bacterial disease in the Office International des Epizooties (OIE) former List ' $A$ ' Diseases.

In sub-Saharan Africa, CBPP is the most important transboundary cattle disease after Rinderpest (OAU-IBAR, 1999) and the Middle East (Rweyemamu et al., 2002). It is a severe disease of high economic importance because of its ability to compromise food security through:

1. Loss of protein and draft power especially in enzootic areas (Tambi et al., 2006).

2. Affects cattle production through morbidity, mortality, retards genetic improvement and limits the ability for the cattle to work (Tambi et al., 2006).

3. Reduce output.

4. Increase production costs due to costs of disease control.

5. Disrupt livestock/product trade.

6. Inhibit sustained investment in livestock production and

7. Cause pain and suffering to animals (Paskin, 2003).

Estimates provided by the Food and Agriculture Organization (FAO, 1990) indicate that animal diseases cause losses of up to $30 \%$ of the annual livestock output in developing countries. The economic impact of this on the economies of developing countries is phenomenal. Masiga et al. (1998) estimated the annual losses directly or indirectly attributable to CBPP to be around US $\$ 2$ billion in African countries. The value of morbidity and mortality losses was estimated at 30 million euros $(2.5$ million per country) while the total economic cost (direct and indirect production losses plus disease control costs) was estimated at 44.8 million euros (3.7 million euros per country). An investment of 14.7 million euros to control CBPP would prevent a loss of 30 million euros. The 
financial return on investment in CBPP control is positive, with benefit-cost ratios that range from 1.61 (Ghana) to 2.56 (Kenya). In the northern part of Nigeria, direct economic cost of CBPP is estimated to be US $\$ 1.5$ million (Egwu et al., 1996).

In Africa, there is significant under-reporting of CBPP due to ineffective surveillance and data- recording systems (Thomson, 2005). Early warning is the key to early reaction for containment, control and rapid elimination to prevent epidemics (FAO 1997). A policy advocated by AU-IBAR (2002) for the control of CBPP include collection of epizootiological data and information to determine and detect foci of infection, that is, surveillance (Babalobi, 2007; Ayling, 2013).

This article is a review of the research application of Participatory Epizootiology to study pastoralism and investigate CBPP in both Igangan Grazing Reserve, Oyo State, Nigeria and in Niger State, Nigeria, between 2007 and 2015 at the Department of Veterinary Public Health and Preventive Medicine, Faculty of Veterinary Medicine, University of Ibadan, Ibadan, Nigeria.

\section{METHODOLOGY}

\section{Case 1}

PE training commenced at the Department of Veterinary Public Health and Preventive Medicine, University of Ibadan, Nigeria since 2004 (Babalobi, 2012a), after Participatory Epizootiology was submitted as a new course by the first author and was officially added and adopted as part of Course PVM 711: Advanced Epizootiology, a compulsory course of the three Masters programs of the Department: - Masters in Preventive Veterinary Medicine (MPVM), Masters in Veterinary Public Health (MVPH) and Master of Science in Epizootiology (MSc Epizootiology); as well as any student (especially government Veterinary Officers), who wish to apply PE for an MPhil/PhD or PhD programme.

The first author subsequently applied and got a University of Ibadan Senate Research Grant SRG/FVM/2006/9A titled 'Participatory Epizootiology Research of the Igangan Grazing Reserve in Ibarapa Agro-Pastoral Zone of Southwest Nigeria (Babalobi, 2007). It sought to apply a Participatory Epizootiology Research Approach to study a Fulani agro-pastoralist settlement scheme, the Igangan Grazing Reserve in Ibarapa Local Government, Oyo State, Southwest Nigeria (Figure 1). The research was undertaken between 2007 and 2009 to get intimated with the history and the present situation of the settlement, the settlement problems, the settlers' expressed needs, and the animal and human health situation of the reserve. The first author then designed a $\mathrm{PhD}$ study research on the Application of Participatory Epizootiology approach to the monitoring and surveillance of CBPP, an enzootic disease identified by settlers in a Fulani agro-pastoralist settlement scheme, the Igangan Grazing Reserve, Oyo state, Southwest Nigeria, West Africa (Babalobi, 2009, 2011a). This was intended to follow up earlier works on control of CBPP in Africa (OAUIBAR, 1999; Thompson, 2005).

On August 15, 2007, Dr. Lawal, the Principal Veterinary Officer of the largely undeveloped 2000 acres (810 hectares) undeveloped Eruwa Veterinary Field Station EVFS, located at Eruwa, the headquarters of Ibarapa East Local Government Area North-west Oyo State, in Southwestern Nigeria, brought to the attention of the first author (who was then the Chairman, EVFS), lung samples which were from diseased cattle brought to his attention by a Pastoralist from the nearby Igangan Grazing Reserve, Ibarapa North Local Government, northwest, Oyo State, South-western Nigeria. A suspected case of Contagious Bovine Pleuropneumonia CBPP around the pastoralist settlement was confirmed by gross and histopathological examination of two infected pieces of lungs submitted for post mortem analysis at the Pathology Unit, Department of Veterinary Pathology, Faculty of Veterinary Medicine, University of Ibadan.

\section{Case 2}

Niger State is in the Northern Guinea Savannah of NorthCentral Nigeria. It is located between latitude $8^{\circ} 20^{\prime} \mathrm{N}$ and $11^{\circ} 30^{\prime} \mathrm{N}$, and longitude $3^{\circ} 30^{\prime} \mathrm{E}$ and $7^{\circ} 20^{\prime} \mathrm{E}$. The study was conducted in three pastoral communities located in the three senatorial zones of the State: Bobi Grazing Reserve in Kontagora zone, Paiko in Minna zone, and Eyagi in Bida zone (Figure 2).

From 2011 to 2015, the second author used the Participatory Epizootiology approach (with other conventional veterinary research approach) to investigate CBPP prevalence in Niger State, North-central Nigeria for his Masters and PhD degrees (Alhaji, 2011; 2014; 2015a, b, c). Study materials used were:

1. Cold box and coolant,

2. Digital camera,

3. Epizootiological kit (vacutainers, vacutainer needles, transport containers, formalin, cotton wool, $20 \mathrm{cc}$ syringe with 18 gauges 11/2" needle, plastic gloves),

4. Recording Materials (notebooks, pens), and

5. Tape recorder, among others.

Qualitative data and 90 blood samples for quantitative serological analysis were collected during the PRA interview of pastoral respondents and observed clinical CBPP diseased cattle respectively. Participatory Rural Appraisal (PRA) Techniques were used to collect Qualitative data. These are the timely methods for the gathering action-oriented information (FAO, 2000).

The Complement Fixation Test (CFT) and competitive Enzyme Linked Immunosorbent Assay (c-ELISA) have 


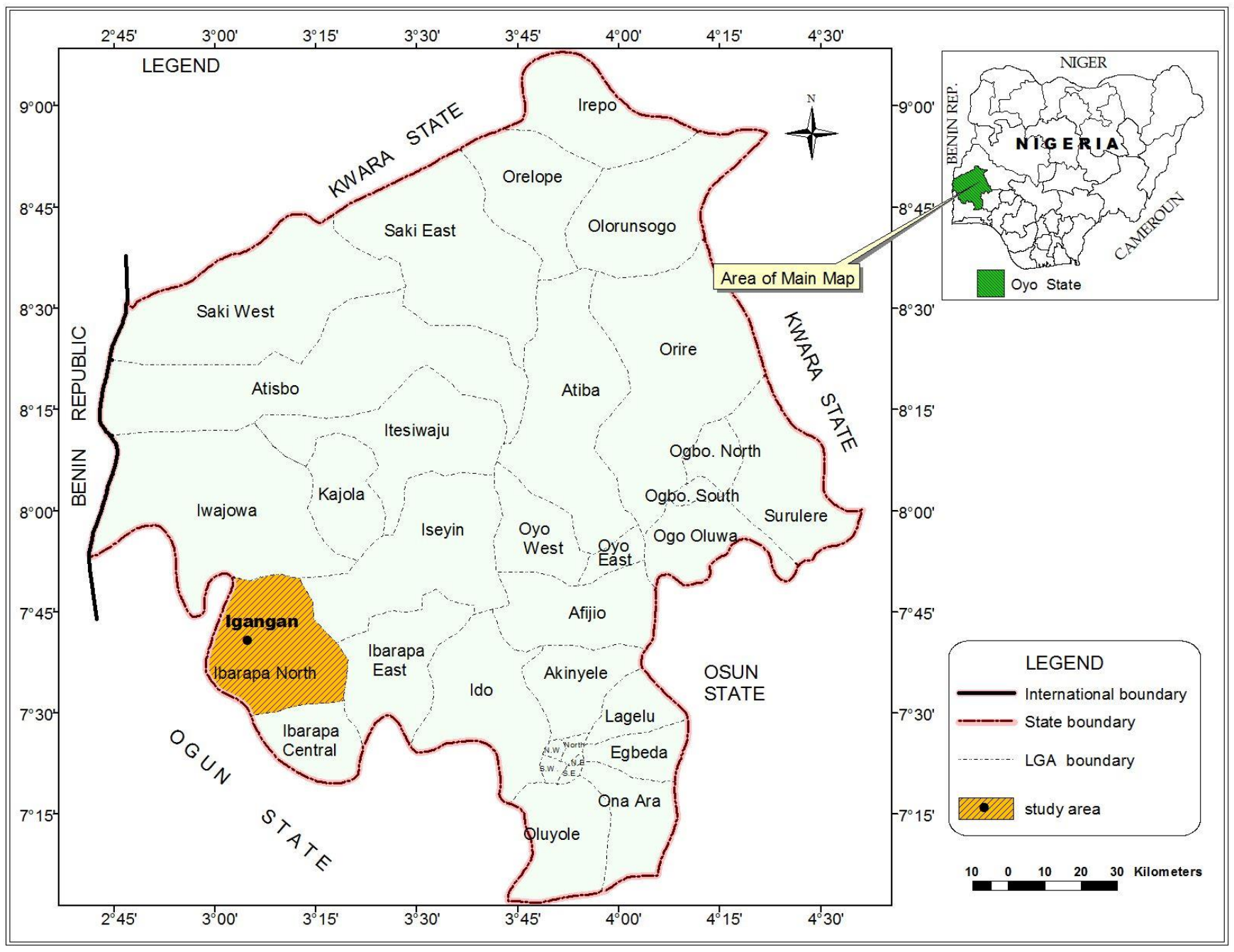

Figure 1. Map showing location of study area in Oyo State, Nigeria.

been recommended by the OIE as herd-level serological diagnostic tests (FAO, 2007). Due to problems encountered with the availability of Complement Fixation Test (CFT) reagents and coupled with its inability to give a fair sensitivity for the CBPP at later stage, cELISA was used for serological analysis. (Aliyu et al., 2003).

The statistical analysis on CBPP prevalence was computed as the number of cattle observed to be infected with the disease at PRA to the total cattle population expressed in percentage (Putt et al., 1987; Thrusfield, 1995). The level of significance between the prevalence of CBPP in the rainy season (April to November) and dry season (December to March) in Niger State were tested statistically using chi-square test at $95 \%$ confidence level and value of $\mathrm{P}<0.05$ are to be considered significant (Steel and Torrie, 1980).

\section{DISCUSSION}

Various PE-based researches have been undertaken at the Department of Veterinary Public Health and Preventive Medicine, University of Ibadan since 2004 when it was approved by the Post-graduate School, University of Ibadan as a compulsory part of the Department's Masters programme (Idowu 2004, Babalobi and Idowu, 2005; Ogunwale, 2007; Ogunwale and Babalobi, 2007; Babalobi, 2007; Babalobi, 2009; Babalobi, et al., 2009; Kareem, 2010; Kareem and Babalobi, 2010; Idowu and Babalobi, 2010; Ogunwale and Babalobi, 2010; Morakinyo, 2010; Babalobi, 2011a; Babalobi and Kareem, 2011; Babalobi, et al., 2011a, Babalobi, et al., 2011b; Alhaji, 2011; Alhaji, 2014; Alhaji, 2015a, b, c; Morakinyo and Babalobi, 2013).

The researches have not only shown the poor animal disease reporting and surveillance status in Nigeria but have also proffered the PE approach as the panacea for improved and effective animal disease reporting and surveillance in the most populated country in Africa, where up to $80 \%$ of livestock are kept in rural communities with virtually no rural based animal health care to tackle recurrent seasonal disease outbreaks and attendant 


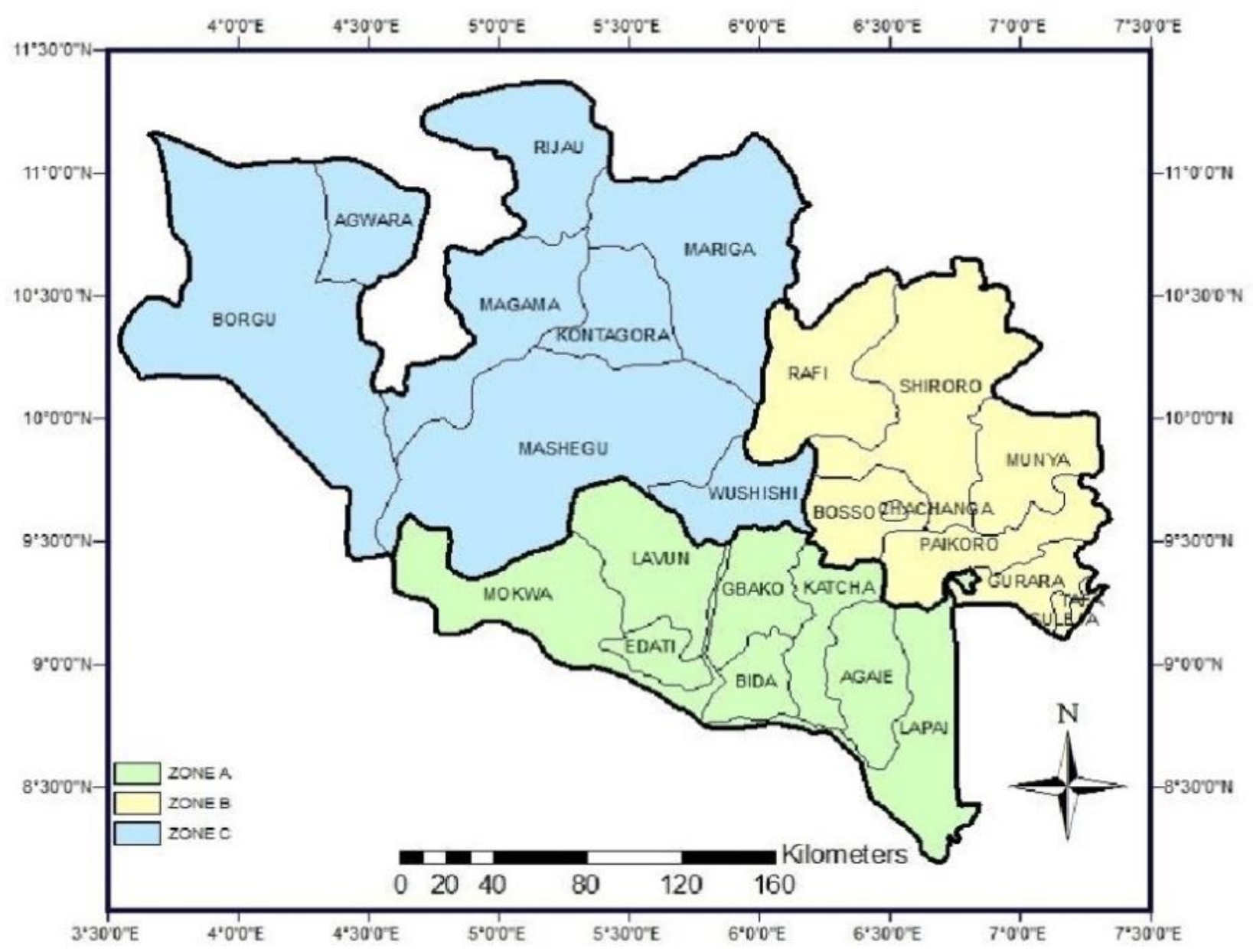

Figure 2. Map of Niger State, Nigeria showing the three Agro-geographical zones A, B and C in the state with their LGAs.

socio-economic and public health consequences (Babalobi 2011a, b; Babalobi et al., 2009).

From the Participatory Epizootiology approach to investigate CBPP prevalence in Niger State, North-central Nigeria, results reveal $77.67 \%$ of CBPP outbreaks in Niger State, Nigeria occur in the dry season, a prevalence of $8.73 \%$ was recorded, and an estimated total economic impact of CBPP of 795.9 million naira (5.21 million dollars) - a relative burden of Contagious Bovine Pleuropneumonia in Niger State, Nigeria were obtained in a 2011 study (Alhaji, 2011). The second authors' PhD result reveals the PE approach can accommodate and be used along other convention veterinary research approach to give concrete and reliable results at that level (Alhaji 2011; Alhaji, 2015; Alhaji and Babalobi, 2014; Alhaji and Babalobi, 2015a, b, c; Alhaji and Babalobi, 2016; Alhaji et al., 2016).

The prevalence of CBPP, number of infections (old and new) that occur in a given cattle population at a given time (Tambi et al., 2006). The prevalence of CBPP varies according to the cattle population system concerned. Prevalence rate tends to be higher in extensive cattle production system, such as the pastoral nomadism. In
Chad, Maho (2001) estimated a CBPP prevalence rate of $1.6 \%$ for cattle raised in a transhumance farming system and rate of $1.2 \%$ for cattle raised in agro-pastoral production systems. In Nigeria, Aliyu et al. (2000) estimated a prevalence rate of $0.29 \%$ from post-mortem examinations of lesions in 81 national abattoirs. Nawathe (1992) also estimated a prevalence rate of $0.51 \%$ in Nigeria, while Kane (2002) reported $2.9 \%$ prevalence rate for Burkina Faso, 5.4\% for Mauritania and $10.5 \%$ for Mali. Wanyoike (1999) and Fikru (2001) reported prevalence rates of $2.8 \%$ and $4.0 \%$ in Kenya and Ethiopia respectively.

\section{CONCLUSION}

While most academics are more into conventional clinical and laboratory-based qualitative veterinary inquiry methodologies, PE is a field of ethnoveterinary/indigenous knowledge based qualitative method not given much value by biased academics. Participatory Epizootiology is a cheap, low capital involvement of traditional settler beneficiaries in identification of enzootic animal problems 
and the Community Based Animal Health training need of settlers. The second authors' PhD result confirms that the PE approach can accommodate and be used along other convention veterinary research approach to give concrete and reliable results at that level (Alhaji, 2011, Alhaji, 2015, Alhaji and Babalobi, 2014; Alhaji and Babalobi, 2015a, b, c; Alhaji and Babalobi, 2016, Alhaji et al., 2016). However, PE Research has the disadvantage that the migratory pattern of settlers affects effective year-round monitoring and surveillance of enzootic disease and may also lead to transboundary transmission of infectious diseases (Babalobi, 2009; 2011a; Babalobi et al., 2009). However, since the formation of the Pan-African Programme for the Control of Epizootics (PACE) in 1999 and the CAPE (Community Based Animal Health and Participatory Epidemiology) Unit of AU/IBAR (African Union/Interafrican Bureau for Animal Resources), the surveillance and reporting in central, eastern and western Africa has improved (AU-IBAR, 2002). Participatory Epizootiology should therefore be adopted in combination with conventional veterinary method for effective Contagious Bovine Pleuropneumonia and other infectious diseases surveillance and control techniques in Africa.

\section{ACKNOWLEDGEMENTS}

Special acknowledgement to the following persons and organization:

1. Andy Catley for initiation into Participatory Epizootiology.

2. Christian Veterinary Missions CVM Seattle-US, for the Participatory Epizootiology training in Jinja, Uganda 2006.

3. Andy Catley, AU-IBAR, Jeff Mariner et al, FAO, IIED, ILRI, OIE etc. for their publications.

4. Department of VPHPM, University of Ibadan for provide the Post-Graduate training and research platform.

5. Dr. Martins A. Lawal of the Faculty Eruwa Veterinary Field Station for providing the diseased lung samples from a settler pastoralist of Igangan Grazing Reserve.

6. Pathology Unit, Department of Veterinary Pathology, Faculty of Veterinary Medicine, University of Ibadan.

7. Departmental postgraduate Participatory Epizootiology Research Project students.

8. University of Ibadan, Nigeria for the Senate Research Grant SRG/FVM/2006/9A.

9. CDC/AFENET/NFELTP for extra- University lecture platforms.

10. ILRI/PENAPH for the invitation to Participatory Epidemiology Network for Animal and Public Health PENAPH Thailand 2012 and.

11. Dr. S.A. Anzaku for presentation on my behalf. At International Conference on Animal Health Surveillance (ICAHS), Lyon, France, 17-20th May 2011.

\section{REFERENCES}

Alhaji, N. B. (2011). Participatory Epizootiological Study of Prevalence and Economic Impact Estimation of Contagious Bovine Pleuropneumonia (CBPP) in Niger State. MPVM degree Project, Department of Veterinary Public Health and Preventive Medicine, University of Ibadan, Ibadan, Nigeria.

Alhaji, N. B. (2015). Epizootiology of Contagious Bovine Pleuropneumonia in Niger State, Nigeria. A Thesis in the Department of Veterinary Public Health and Preventive Medicine Submitted to the Faculty of Veterinary Medicine in partial fulfillment of the requirements for the degree of Doctor of Philosophy $\mathrm{PhD}$ of the University of Ibadan, November 2015.

Alhaji, N. B., \& Babalobi, O. O. (2014). The Use of Participatory Epizootiology to Investigate Burden and Seasonal Occurrence of Contagious Bovine Pleuropneumonia in Pastoral Communities of Niger State, Nigeria. Poster presentation at $t$ the 51st Annual Congress of the Nigerian Veterinary Medical Association (NVMA KADA 2014) holding at the Umaru Musa Yar'Adua Indoor Sport Centre, Murtala Square, Kaduna 23rd to 28th November 2014.

Alhaji, N. B., \& Babalobi, O. O. (2015a). Participatory Epidemiology of Ethnoveterinary Practices Fulani Pastoralists Used to Manage Contagious Bovine Pleuropneumonia and Other Cattle Ailments in Niger State, Nigeria. Journal of Veterinary Medicine, vol. 2015, Article ID 460408, 10 pages.

Alhaji N. B., \& Babalobi O. O. (2015b). Socio-cultural factors influencing transmission of Mycoplasma mycoides small colony in pastoral cattle herds of north-central Nigeria. Vom Journal of Veterinary Science, 10, 1-13.

Alhaji, N. B., \& Babalobi, O. O. (2015c). Sero-positivity and associated risk factors of contagious bovine pleuropneumonia under two cattle production systems in North-central Nigeria. Tropical Animal Health and Production, 43(2), 311-320.

Alhaji, N. B., \& Babalobi, O. O. (2016). Qualitative and quantitative impacts assessment of contagious bovine pleuropneumonia in Fulani pastoral herds of North-central

Nigeria: The associated socio-cultural factors. Preventive Veterinary Medicine, 128,124-128.

Alhaji, N. B., Babalobi, O. O., \& Saidu, S. (2016). Using seropositivity to assess geospatial burden of contagious bovine pleuropneumonia on pastoral cattle herds of north-central Nigeria. Pastoralism, 6(1), 20.

Aliyu, M. M., Obi, T. U. Oladosu, L. A., Egwu, G. O., Ameh, J. A. (2003). The Use of Competitive Enzyme Linked ImmunoSorbent Assay in Combination with Abattoir Survey for CBPP Surveillance in Nigeria. Tropical Veterinarian, 21(2), 35-41.

Aliyu, M. M., Obi, T. U., \& Egwu, G. O. (2000). Prevalence of contagious bovine pleuropneumonia (CBPP) in northern Nigeria. Preventive Veterinary Medicine, 47(4), 263-269.

Anzaku, S. A. (2009). Participatory Approaches in Disease Surveillance: The Nigeria Experience. Presented at the Nigeria Short Course on Control of Zoonotic Infections, Surveillance, Investigation, Detection and Response, National Veterinary Research Institute NVRI, Vom, Plateau State, Nigeria. October 13, 2009.

AU-IBAR (2002). Contagious bovine pleuropneumonia in pastoral areas of East Africa: disease dynamics and control options. African Union-Interafrican Bureau for Animal Resources, Nairobi, Kenya.

Ayling, R. (2013). Meeting Report, Contagious Bovine Pleuropneumonia Workshop, ILRI, Addis Ababa. IOM Newsletter, 37, 10-15. 
Babalobi O. O. (2007). Participatory Epizootiology Research of the Igangan Grazing Reserve in Ibarapa Agro-Pastoral Zone of Southwest Nigeria. University of Ibadan Senate Research Grant 2006 SRG/FVM/2006/9A.

Babalobi, O. (2009). Participatory approach to the monitoring and surveillance of Contagious Bovine Pleuropneumonia disease outbreak among settled pastoralists at Igangan grazing reserve, Oyo State Southwest, Nigeria: In Linda Hoinville, Joey Ellis-Iversen, Daan Vink, Eamon Watson, Lucy Snow and Jane Gibbens (2009): Discussing the Development and Application of Methods for Effective Surveillance in Livestock Populations Report of Pre-ISVEE XII workshop- Methods for effective surveillance. 'Epidemiology Unplugged-Providing power for better health': The Twelfth Conference of the International Society for Veterinary Epidemiology and Economics (ISVEE XII), Pre-ISVEE XII workshop, August 6-8. Durban, Republic of South Africa.

Babalobi, O. O. (2011a). A Participatory Epizootiology Research of Settled Pastoralists in Igangan Grazing Reserve, Southern Guinea Agro-Pastoral Zone, Oyo State, Nigeria: First Report. Nigerian Veterinary Journal, 32(1), 16-20.

Babalobi, O. O. (2011b). ILRI- Early Detection Reporting Surveillance: Avian Influenza in Africa (EDRSAIA) Key Informant Evaluation Questionnaire. Department of Veterinary Public Health and Preventive Medicine, University of Ibadan, Ibadan, Nigeria. March 14, 2011. 8p.

Babalobi, O. O. (2012a). Eight years (2004-2012) of teaching Participatory Epidemiology at the University of Ibadan, Nigeria. Oral presentation at Participatory Epidemiology Network for Animal and Public Health (PENAPH) Technical Workshop held at the Veterinary Public Health Centre for Asia Pacific (VPHCAP) at the Faculty of Veterinary Medicine, Chiang Mai University/Imperial Maeping Chiang Mai Hotel, Chiang Mai, Thailand. December $11-13,2012$.

Babalobi, O. O. (2012b). Participatory Epidemiology Approach to the prevention and control of infectious and non-infectious diseases in animals and humans. 15th International Conference on Infectious Diseases. Bangkok, Thailand. June 13-16, 2012.

Babalobi, O. O., Bolajoko M. B., \& Anzaku, S. A. (2011a) Participatory animal disease surveillance, panacea to the bane of animal disease under-reporting in Nigeria. Epidémiol. et santé anim, 59-60, 273-275. Proceedings, International Conference on Animal Health Surveillance (ICAHS), Lyon, France, 17-20th May 2011.

Babalobi, O. O., Bolajoko, M. B., \& Anzaku, S. A. (2011b). Participatory Disease Surveillance as Panacea to the Bane of Animal Disease Under-Reporting in Nigeria: A Collaborative Research. Short Communication. Tropical Veterinarian, 29(3), 36-40.

Babalobi, O. O., \& Idowu O. (2005). The Paradigm of Community-Based Participatory Epizootiology: A Review. Tropical Veterinarian, 23(3\&4), 69-77.

Babalobi, O. O., Idowu, O. S., \& Lawal A. M. (2009). Participatory Epizootiology Research of Settled Pastoralists of the Igangan Grazing Reserve, Oyo state, Southwest Nigeria. 'Epidemiology Unplugged-Providing power for better health': The Twelfth Conference of the International Society for Veterinary Epidemiology and Economics (ISVEE XII). 10 - 14 August 2009, Durban, South Africa. http://www.sciquest.org.nz/node/67816. p 342.

Babalobi, O. O., \& Kareem, A. A. (2011). Participatory Baseline Survey of a Case Study Rural Livestock Health Management Practice in Nigeria: The Place of Community Based Animal
Health Workers. Tropical Veterinarian, 29(2).

Catley, A. (1999). Methods on the Move: a review of veterinary uses of participatory approaches and methods focusing on experiences in dryland Africa. International Institute for Environment and Development, London. Intelligence. Draft document prepared for FAO. Vetwork UK, Musselburgh and RDP Livestock Services b.v., Zeist.

Catley, A. (2005). Participatory Epidemiology: A Guide for Trainers. African Union/Interafrican Bureau for Animal Resources, Nairobi.

Catley, A., \& Admassu, B. (2003). Using participatory epidemiology to assess the impact of livestock diseases. FAOOIE-IAEA Consultative Group Meeting on Contagious Bovine Pleuropneumonia in Africa.12-14 November 2003, Rome, Italy.

Catley, A., \& Mariner, J. (2002). Where there is no data: Participatory approaches to veterinary epidemiology in pastoral areas of the Horn of Africa. IIED issues Paper No 110. International Institute for Environment and Development, London.

Catley A., \& Leyland, T. (2001). Community participation and the delivery of veterinary services in Africa, Preventive Veterinary Medicine, 49 95-113.

Catley, A., \& Mariner J. (Eds.) (2001). Participatory epidemiology: lesson learned and future directions. Proceedings of a workshop held in Addis Ababa, Ethiopia, Nov.15th-17th 2001.

Egwu, G. O., Nicholas, R. A. J., Ameh, J. A., \& Bashirrudin, J. B. (1996). Contagious bovine pleuropneumonia: An update. Veterinary Bulletin, 66(9), 875-888.

FAO (1990). Cost/benefit analysis for animal health programmes in developing countries. Food and Agriculture Organization (FAO) Expert Consultation, Rome, Italy.

FAO (1997). Recognizing CBPP: A Field Manual for Recognition. Available http://www.fao.org/docrep/004/AC147E/AC147E00.HTM.

FAO (2000). Food and Agriculture Organization, FAO/EMPRES Manual on Participatory Epizootiology, Rome, Italy. Pp. 1-32. http://www.fao.org/docrep/003/X8833E/X8833e03.htm

FAO (2003). Final Research Co-ordination Meeting of the FAO/IAEA Coordinated Research Programme on the "Monitoring of Contagious Bovine Pleuropneumonia in Africa Using Enzyme Immunoassays". 21 February, Bamako, Mali.

FAO (2007). Summary of recommendations. Report of the Fourth Meeting of the FAO-OIE-AU/IBAR-IAEA Consultative Group on Contagious Bovine Pleuropneumonia (CBPP), Rome, Italy. 6-8 November 2006. Rome: FAO: 13-15.

FAO (2012). Lessons learned from the eradication of Rinderpest for controlling other transboundary animal diseases. Proceedings of the GREP Symposium and High-Level Meeting, 12-15 October 2010, Rome, Italy. FAO Animal Production and Health Proceedings, No. 15. Rome, Italy Fikru, R. (2001). Herd prevalence of CBPP, bovine tuberculosis and dictyocaulosis in Budju woreda, West Wellega. DVM Thesis, Addis Ababa University, Faculty of Veterinary Medicine, Debre Zeit.

Idowu O. S., \& Babalobi O. O. (2010). Animal Health Management Perspectives of Rural Livestock Farmers in Southwest Nigeria: The Place of Community Based Animal Health Workers. Nigerian Veterinary Journal, 31(1), 26-36.

Kane, M. (2002). Etude historique sur la peripneumonia contagieuse bovine au Burkina Faso, Cote d'Ivoire, Guinee, Mali, Mauritanie, Niger et Senegal. Consultancy report produced for the African Union Inter-African Bureau for Animal Resources - Pan African Programme for the Control of 
Epizootics, AU/IBAR-PACE, Nairobi.

Kareem, A. A. (2010). A Participatory Baseline Survey of Rural Livestock Health Management Practices in Igangan Agro Pastoral Zone, Oyo State Nigeria: The place of Community Based Animal Health Workers. MPVM degree Project, Department of Veterinary Public Health and Preventive Medicine, University of Ibadan, Ibadan, Nigeria.

Kareem, A. A., \& Babalobi, O. O. (2010). Participatory Baseline Survey of Rural Livestock Health Management Practices in Igangan Agro -Pastoral Zone, Oyo State Nigeria: The Place of Community Based Animal Health Workers. Presented at the 2010 47th Annual Congress of the Nigerian Veterinary Medical Association, Makurdi, Benue State. October 2010.

Maho, A. (2001). Etude historique sur la peripneumonie contagieuse bovine au, Tchad. Consultancy report produced for the African Union Interafrican Bureau for Animal Resources-Pan African Programme for the Control of Epizootics. AU/IBAR-PACE, Nairobi, Kenya.

Mariner, J. C., \& Paskin, R (2000). Manual on Participatory Epidemiology. FAO Animal Health Manual No. 10. Food and Agriculture Organization, Rome. http://www.fao.org/docrep/003/X8833E/x8833e03.htm

Masiga, W. N., Rossiter, P., \& Bessin, B. (1998). Present situation of CBPP in Africa and epidemiological trends. In: Report of the first meeting of the FAO/OIE/OAU-IBAR Consultative Group on Contagious Bovine Pleuropneumonia, 5-7 October, Rome, FAO, Rome, Italy, 25-31.

Morakinyo, O. A. (2010). Participatory Appraisal of Peste des Petite Ruminante (PPR) in Iseyin Local Government Area of Oyo State, Nigeria. MPVM degree Project, Department of Veterinary Public Health and Preventive Medicine, University of Ibadan, Ibadan, Nigeria.

Morakinyo O. A., \& Babalobi, O. O. (2013). Participatory Appraisal of Peste des Petite Ruminants (PPR) outbreaks in Iseyin Local Government Area of Oyo State, Nigeria. Proceedings of the 11th annual congress of the Southern African Society for Veterinary Epidemiology and Preventive Medicine. 14-16 August 2013. Salt Rock, KZN, Republic of South Africa. Pp. 28-33.

Narayan, D. (1996). Towards Participatory Research. World Bank Technical Paper Number 307, The World Bank, Washington, DC.

Nawathe, D. R. (1992). Resurgence of contagious bovine pleuropneumonia in Nigeria. Revue Scientifique et Technique; Office international des epizooties, 11 (3), 799-804.

OAU-IBAR (1999). PARC Provisional Final Report 1986-1999. Pan-African Programme for the Control of Epizootics and PanAfrican Rinderpest Campaign: Information Resource CDROM Vol. 2. African Union-Interafrican Bureau for Animal Resources, Nairobi, Kenya.

Ogunwale, C. I. (2007). Participatory Appraisal of Livestock Diseases with Livestock Keeping Women of Awotan, Ido LGA, Oyo State, Nigeria. A Research Project Report submitted to the Department of Veterinary Public Health and Preventive Medicine, Faculty of Veterinary Medicine, University of Ibadan, Nigeria, in partial fulfillment of requirements for the award of the degree of Master of Veterinary Public Health (MVPH).

Ogunwale, I., \& Babalobi, O. O. (2007). Community Based Participatory Epizootiology of Livestock kept by Awotan Women, Ido LGA, Oyo State, Nigeria. Proceedings, Scientific Session of the 44th Annual Congress of the Nigerian
Veterinary Medical Association, Warri Delta State, Nigeria. October 2007. Pp. 293-296.

Ogunwale, I., \& Babalobi, O. O. (2010). Ethno-Veterinary Medicine Perspectives of Common Diseases and Health Problems of Livestock kept by Rural Women in South-West Nigeria: A Case Study. Nigerian Veterinary Journal, 31(4), 255-262.

OIE (1995). Meeting of the FMD and other Epizootics Commission. Office international des epizooties, Paris, France, 16-20 January.

OIE (2005). Terrestrial Animal Health Code. Office international des epizooties: Paris, France.

OIE (2011). The Odyssey of Rinderpest Eradication. http://www.oie.int/en/for-the-media/editorials/detail/article/theodyssey-of-rinderpest-eradication/

Paskin, R. (2003). Economic and social welfare importance of transboundary animal diseases. In: Report of a workshop of Chief Veterinary Officers/Directors of Veterinary Services of SADC Member Countries on Transboundary Animal Diseases with special reference to foot and mouth disease and contagious bovine pleuropneumonia in Southern Africa, Pretoria, 21-22 July, South Africa.

Putt, S. N. H., Shaw, A. P. M., Woods, A. J., Tyler, L., \& James, A. D. (1987). Veterinary epidemiology and economics in Africa: A manual for use in the design and appraisal of livestock health policy. ILCA Manual No. 3, Addis Ababa, Ethiopia. Pp. 23-24.

Rweyemamu, M., Paskin, R., \& Benkirane, A. (2002). Emerging Diseases of Africa and the Middle East. Annals of the New York Academy of Sciences 916(1), 61-70.

Shimshony, A. (2009) Participatory surveillance (involving (farmers and paraprofessionals). OIE conference Session 2: Early detection, notification and surveillance. Evolving veterinary education for a safer world Maison de la Chimie, Paris, 12-14 Oct 2009 http://www.oie.int/fileadmin/Home/eng/Conferences_Events/si tes/deans2009/ptt_deans/Tuesday/Shimshony-PE-PDS-OIEPARIS\%2013.10.2009-.pdf

Schwabe, C. W. (1984). Veterinary Medicine and Human Health, Williams and Wilkins, Baltimore, 680p.

Steel, G. D. \& Torrie, J. H. (1980). Principles and procedure of statistics: Biomedical approach (2nd Ed.). McGraw Hill publ. Inc., New York.

Tambi, N. E., Mania, W. O., \& Ndi, C. (2006). An estimation of the economic impact of contagious bovine pleuropneumonia in Africa. Review Scientifique et Technique; Office international des epizooties, 25(3), 999-1012.

Thomson, G. R. (2005). Contagious bovine pleuropneumonia and poverty: A strategy for addressing the effects of the disease in sub-Saharan Africa. Research report, DFID Animal Health Programme, Centre for Tropical Veterinary Medicine, University of Edinburgh, UK. (Which was based on Dr. Jeff Mariner's work, initially reported as the dynamics of CBPP endemism and the development of effective control/eradication strategies for pastoral communities (Mariner, 2003)

Thrusfield, M. (1995). Veterinary epidemiology 2nd Ed., University of Edinburgh, Blackwell Science, UK, Pp. 180-188.

Wanyoike, S. W. (1999). Assessment and mapping of contagious bovine pleuropneumonia in Kenya, past and present. M. Sc. Thesis. Freie Universitat Berlin and Addis Ababa University. 


\section{APPENDIX}

Conference Proceedings and Publications of Authors (Babalobi O. O. and Alhaji N.B) on the application of Participatory Epizootiology on Contagious Bovine Pleuro-Pneumonia and other related articles (2005 - 2017).

1. Babalobi O.O. and Idowu O. (2005): The Paradigm of Community-Based Participatory Epizootiology: A Review. Tropical Veterinarian. Vol. 23 (3\&4) 69-77. 34.

2. Ogunwale Ibironke and Babalobi O. O. (2007): Community Based Participatory Epizootiology of Livestock kept by Awotan Women, Ido LGA, Oyo State, Nigeria. Proceedings, Scientific Session of the 44th Annual Congress of the Nigerian Veterinary Medical Association, Warri Delta State, Nigeria. Pp. 293-296.

3. Babalobi O. O (2009): Application of Participatory Epizootiology approach to the monitoring and surveillance of Contagious Bovine Pleuro-pneumonia among settled pastoralist at the Igangan Grazing Reserve, Oyo state, Southwest Nigeria. In Linda Hoinville, Joey Ellis-Iversen, Daan Vink, Eamon Watson, Lucy Snow and Jane Gibbens (2009): Discussing the Development and Application of Methods for Effective Surveillance in Livestock Populations Report of Pre-ISVEE XII workshop- Methods for effective surveillance. 'Epidemiology Unplugged-Providing power for better health': The Twelfth Conference of the International Society for Veterinary Epidemiology and Economics (ISVEE XII), Durban, South Africa, August 2009 as rep_pres_zisvee page2appendices.pdf http://vla.defra.gov.uk/reports/docs/rep_pres_isvee_babalobi.pdf.

4. Babalobi O. O. (2009): Participatory Epizootiology Research of Settled Pastoralists of the Igangan Grazing Reserve, Oyo state, Southwest Nigeria. 'Epidemiology Unplugged-Providing power for better health': The Twelfth Conference of the International Society for Veterinary Epidemiology and Economics (ISVEE XII). 10 - 14 August 2009, Durban, South Africa. p 342. http://www.sciquest.org.nz/node/67816. P 342.

5. Ogunwale I. and Babalobi O. O. (2010): Ethno-Veterinary Medicine Perspectives of Common Diseases and Health Problems of Livestock kept by Rural Women in South-West Nigeria: A Case Study. Nigerian Veterinary Journal Vol. 31(4) 255-262.

6. Babalobi O. O. (2011): A Participatory Epizootiology Research of Settled Pastoralists in Igangan Grazing Reserve, Southern Guinea Agro-Pastoral Zone, Oyo State, Nigeria: First Report. Nigerian Veterinary Journal, Vol. 32. (1). 1620.

7. Babalobi O. O. and Kareem A. A. (2011): Participatory Baseline Survey of a Case Study Rural Livestock Health Management Practice in Nigeria: The Place of Community Based Animal Health Workers. Tropical Veterinarian. Vol. $29(2)$

8. Babalobi O.O., M.B. Bolajoko and S.A. Anzaku (2011): Participatory animal disease surveillance, panacea to the bane of animal disease under-reporting in Nigeria. Epidémiol. et santé anim, 59-60, 273-275. Proceedings, International Conference on Animal Health Surveillance (ICAHS), Lyon, France, 17-20th May 2011. http://aeema.vetalfort.fr/public/pdf/revue/59.00.pdf'eport.

9. Babalobi O. O., Bolajoko, M.B. and Anzaku S.A. (2011): Participatory Disease Surveillance as Panacea to The Bane of Animal Disease Under-Reporting in Nigeria: A Collaborative Research. Short Communication. Tropical Veterinarian. 29. (3) 36-40.

10. Alhaji N. B. (2011): Participatory Epizootiological Study of Prevalence and Economic Impact Estimation of Contagious Bovine Pleuropneumonia (CBPP) in Niger State. MPVM degree Project, Department of Veterinary Public Health and Preventive Medicine, University of Ibadan, Ibadan, Nigeria.

11. Morakinyo O.A. and Babalobi O. O. (2013): Participatory Appraisal of Peste des Petite Ruminants (PPR) outbreaks in Iseyin Local Government Area of Oyo State, Nigeria. Proceedings of the 11th annual congress of the Southern African Society for Veterinary Epidemiology and Preventive Medicine. 14-16 August 2013. Salt Rock, KZN, Republic of South Africa p 28-33.

12. Alhaji N. B. and Babalobi O. O. (2014): The Use of Participatory Epizootiology to Investigate Burden and Seasonal Occurrence of Contagious Bovine Pleuropneumonia in Pastoral Communities of Niger State, Nigeria. Poster presentation at $t$ the 51 st Annual Congress of the Nigerian Veterinary Medical Association (NVMA KADA 2014) holding at the Umaru Musa Yar'Adua Indoor Sport Centre, Murtala Square, Kaduna (23rd to 28th November 2014).

13. Alhaji \& Babalobi 2015: 'Molecular epidemiology of contagious bovine pleuropneumonia by detection, identification and differentiation of Mycoplasma mycoides subsp. mycoides in Niger State, Nigeria'. Sokoto Journal of Veterinary Sciences (2015) 13(3): 1-8.

14. Alhaji N. B. (2015): Epizootiology of Contagious Bovine Pleuropneumonia in Niger State, Nigeria. A Thesis in the Department of Veterinary Public Health and Preventive Medicine Submitted to the Faculty of Veterinary Medicine in partial fulfillment of the requirements for the degree of Doctor of Philosophy PhD of the University of Ibadan, November 2015. 
15. Alhaji N. B. and Babalobi O. O. (2014): The Use of Participatory Epizootiology to Investigate Burden and Seasonal Occurrence of Contagious Bovine Pleuropneumonia in Pastoral Communities of Niger State, Nigeria. Poster presentation at $t$ the 51st Annual Congress of the Nigerian Veterinary Medical Association (NVMA KADA 2014) holding at the Umaru Musa Yar'Adua Indoor Sport Centre, Murtala Square, Kaduna 23rd to 28th November 2014.

16. Alhaji, N. B., \& Babalobi O. O. (2015). Socio-cultural factors influencing transmission of Mycoplasma mycoides small colony in pastoral cattle herds of north-central Nigeria. Vom Journal of Veterinary Science, 10: 1-13. Accepted: 3rd June 2015.

17. Alhaji N. B. \& Babalobi, O. O. (2015). Participatory Epidemiology of Ethnoveterinary Practices Fulani Pastoralists Used to Manage Contagious Bovine Pleuropneumonia and Other Cattle Ailments in Niger State, Nigeria. Journal of Veterinary Medicine, Volume 2015, Article ID 460408, 10 pages. doi.org/10.1155/2015/460408. Accepted: 24 January 2015.

18. Alhaji, N. B., \& Babalobi, O. O. (2015). Molecular epidemiology of contagious bovine pleuropneumonia by detection, identification and differentiation of Mycoplasma mycoides subsp. mycoides in Niger State, Nigeria. Sokoto Journal of Veterinary Sciences, 13(3), 1-8. Accepted: 17 August 2015.

19. Nma B. Alhaji and Olutayo O. Babalobi, 2016. Sero-positivity and associated risk factors of contagious bovine pleuropneumonia under two cattle production systems in North-central Nigeria. Tropical Animal Health and Production. 43(2): 311-320. DOI 10.1007/s11250-015-0952-y. Accepted: 29 October 2015.

20. Alhaji N. B. and Babalobi O. O. (2016): 'Qualitative and quantitative impacts assessment of contagious bovine pleuropneumonia in Fulani pastoral herds of North-central Nigeria: The associated socio-cultural factors'. Preventive Veterinary Medicine. (2016) 128:124-128. Accepted April 6, 2016. 